\title{
Shareowners, Stakeholders $\&$ the Global Oversize Economy. The Coca-Cola Company Case
}

\author{
Silvio M. Brondoni*
}

\begin{abstract}
Since 2010, globalisation has imposed a new view of the competitive environment in which competitors are not always direct rivals. On the contrary, as a result of alliances and agreements, certain firms can become mega-organisations that have the potential to change the long-term competitive structure of sectors (oversize economy). In the emerging oversize economy, mega corporations (The Coca-Cola Company, McDonald's, Apple, for instance) manage competition adopting firm policies focused on shareownership, co-ownership and stock splits. The Coca-Cola Company accountability for sustainability creates a range of outcomes including diverse beverage products; economic benefits such as jobs, taxes paid and community investment; ecosystem impacts and initiatives; and customer and shareowner value.
\end{abstract}

Keywords: Shareowners; Stakeholders; Oversize Economy; Global Competition; The Coca-Cola Company

\section{Oversize Economy, Shareownership and Global Competition}

From the beginning of the 2010s and up to these years, a new phase of globalisation produced a structural change in competition (network globalisation 2010-2020). The primacy of knowledge management, the worldwide localization of production and the new policies of innovation and imitation have been modified in opportunities for worldwide joint ventures, global competitive alliances and merger and acquisitions (Brondoni, 2012). As a result of concentration, fusions in several industries have involved a 'mega-merger' of corporate giants that has radically transformed the competitive balance in many sectors (Brondoni, 2014).

Since 2010, globalisation has imposed a new view of the competitive environment in which competitors are not always direct rivals. On the contrary, as a result of alliances and agreements, certain firms can become competitors in the sense that together they contribute to the common objective of generating greater profits, with mega-organisations that have the potential to change the long-term competitive structure of sectors (oversize economy) (Brondoni \& Bosetti, 2018).

*Editor-in-Chief Symphonya. Emerging Issues in Management (silvio.brondoni@unicusano.it)

Edited by: Niccolò Cusano University

ISSN: 1593-0319

Brondoni, S.M. (2019). Shareowners, Stakeholders \& the Global Oversize Economy. The CocaCola Company Case, Symphonya. Emerging Issues in Management (symphonya.unicusano.it), 1, 16-27.

http://dx.doi.org/10.4468/2019.1.02brondoni 
$\square$ Indeed, since the mid-2010, the competitive dynamics of corporations in the global agrochemical market have changed rapidly and profoundly. In particular, the largest companies have drastically increased the concentration of global supply, leading to the abandonment of corporate policies based on oversupply to instead emphasise new competitive policies focused on the global supply concentration economy (big corporations based on global networks, lean and multicultural organisations, basic techno products, global supply, high profits) to affirm a new oversize economy competitive dynamic. The importance of company size is evident. The mergers between ChemChina-Syngenta, DowDuPont, and Bayer-Monsanto highlight that business development policies assume a simple key focus: continue to grow to remain competitive (Brondoni \& Bosetti, 2018).

Furthermore, globalisation has led to breaking down boundaries, thus becoming very difficult today to clearly define the boundaries and business activity areas. In fact, a given firm may be a rival or a competitor of other companies in different markets.

In today's scenario of 'hypercompetition', global corporations face to many other MNCs (more and more based in US, China, South Korea, Taiwan and Europe). In this new competitive landscape, capitalism breaks the static, monolithic rules of the company that plans, produces and sells by the rules of absolute proximity (local market) or relative proximity (international market). Global networks by converse assert more complex and articulated structures that disregard traditional rules of corporate responsibility (for example, in terms of quotas of national workers to hire) and 'local' conduct based on social responsibility. Instead they refer to often impalpable standards of 'network corporate responsibility' (which envisages the fragmentation of corporate responsibility centres and various hierarchical levels of social responsibility, dispersed in space and changing in time, and often not easy to identify) (Brondoni, 2014).

In global managerial economics, more and more characterised by over-sized corporations, firms operate in networks that must continuously interact on a global scale with a varying and constantly changing group of stakeholders (Salvioni, 2002).

Any socially responsible company strives to meet all relevant stakeholders' expectations (Freeman \& Dmytriyev, 2017), and this requires acknowledging the close links among economic, social and environmental performance for the creation of shared value and lasting prosperity (Salvioni \& Gennari, 2017; Porter \& Kramer, 2006).

In particular, adoption of firm policies focused on stakeholders (short-term development), shareholders (short-term profitability), or on shareowners (long-term vision and growth), implies different policies in firm performance assessment, based on the equitable balance between competitive, financial and socioenvironmental variables (Salvioni 2003).

In the emerging oversize economy, mega corporations (The Coca-Cola Company, McDonald's, Apple, for instance) manage competition adopting firm policies 
focused on shareowners, co-owners and stock splits.

Co-owned companies tend to be more successful, competitive, profitable and sustainable, because co-owners tend to be more entrepreneurial and committed to the company and its success. Because they have high employment standards, involve staff and give everyone a stake, co-owners are better at recruiting and retaining talented, committed staff. Co-owners tend also to have a strong commitment to corporate social responsibility and involvement with the communities because they operate in an open marketspace. Finally, co-owned companies are more innovative because managers go out of their way to consult, share information about the company, and give staff responsibility.

In this sense, for the Coca-Cola Company there is a difference between holding shares as a shareowner of record and as a beneficial owner. If shares are registered directly in the name of the beneficial owner with the Company's registrar and transfer agent, Computershare Trust Company, N.A., the beneficial owner is considered a shareowner of record with respect to those shares; if shares are held in a brokerage account or bank, trust, or other nominee, the investor is considered the 'beneficial owner' of those shares. The Company normally pays dividends four times a year, usually April 1, July 1, October 1 and December 15. Shareowners of record can elect to receive their dividend payments electronically or by check in the currency of their choice.

$\square$ The Shareowners View of The Coca-Cola Company defines 'A business focused on sustainability demands integrity in every respect. The Board of Directors of The Coca-Cola Co. is elected by shareowners to oversee their interest in the long-term health and the overall success of the Company's business and its financial strength. The Board serve as the ultimate decisionmaking body of the company, except for those matters reserved to, or shared with, the shareowners. The Board currently has 17 members, 16 of whom are not employees of The Coca-Cola Company. The Coca-Cola Company is committed to good corporate governance, which promotes the long-term interests of shareowners, strengthens Board and management accountability and helps build public trust in the Company' (The Coca-Cola Company GRI Report 2012-1013, pp.76-78) (Brondoni, 2014).

Finally, in the global oversize competition, the shareowners view and the coownership commitment can be empathized with specific stock split measures. A stock split means that existing shareholders receive additional shares, but the value of the shares will not increase due to the stock split. When a stock split is announced, an options contract undergoes an adjustment called "being made whole". 


\section{The Coca-Cola Global Business in the Oversize Competition}

Since its birth at a soda fountain in downtown Atlanta, Georgia, in 1886, Coca-Cola has been a catalyst for social interaction and inspired innovation. These unique moments in history, arranged in chronological sequence, have helped create a global brand.

$\square$ Dr John S. Pemberton is the founder of Coca Cola. Dr Pemberton started the Coca-Cola Company in 1886. $\mathrm{Dr}$ Pemberton was an Atlanta pharmacist who created a flavoured syrup that resulted in an excellent soda when combined with carbonated water. Frank M. Robinson, Dr Pemberton's bookkeeper and partner, came up with the idea of naming the drink Coca-Cola. Dr Pemberton and Robinson did not remain sole owners for long. By the time Dr Pemberton died in 1888, he had sold fractions of his business to different parties. The majority shareholder at the time was Asa G. Candler, an Atlanta businessman.

The Coca-Cola Company owns or licenses and markets non-alcoholic beverage brands, primarily sparkling beverages and a range of still beverages, such as waters, flavoured waters and enhanced waters, juices and juice drinks, ready-to-drink teas and coffees, sports drinks, dairy and energy drinks. The Company's segments include Europe, Middle East and Africa; Latin America; North America; Asia Pacific; Bottling Investments, and Corporate.

$\square$ The Company owns and markets a range of non-alcoholic sparkling beverage brands, including Coca-Cola, Diet Coke, Fanta and Sprite. As of December 31, 2018, the Company owned or licensed and marketed over 500 non-alcoholic beverage brands. The Company markets, manufactures and sells beverage concentrates, which are referred to as beverage bases, and syrups, including fountain syrups (concentrate business or concentrate operations), and finished sparkling and still beverages (finished product business or finished product operations). The Company makes its beverage products available to consumers across the world through its network of Companyowned or -controlled bottling and distribution operations, as well as bottling partners, distributors, wholesalers and retailers.

The Coca-Cola system is a global business that operates on a local scale. The Company is able to create global reach with local focus because of the strength of the Coca-Cola system, which comprises the Company and nearly 250 bottling partners worldwide.

The Coca-Cola system is not a single entity from a legal or managerial perspective, and the Company does not own or control all the bottling partners. 
The Coca-Cola system operates through multiple local channels. The marketplace starts with Coca-Cola, which manufactures and sells concentrates, beverage bases and syrups to bottling operations. Coca-Cola also owns the brands and is responsible for consumer brand marketing initiatives. Bottling partners manufacture, package, merchandise and distribute final branded beverages to customers and vending partners, who then sell the products to consumers.

All bottling partners work closely with customers - grocery stores, restaurants, street vendors, convenience stores, movie theatres and amusement parks, among many others - to execute localized strategies developed in partnership with the company. Customers then sell the products to consumers.

The Company sells concentrates and syrups to authorized bottling and canning operations (bottlers or its bottling partners). Its bottling partners either combine the concentrates with sweeteners (depending on the product), still water and/or sparkling water, or combine the syrups with sparkling water to produce finished beverages. The finished beverages are packaged in authorized containers, such as cans and refillable and non-refillable glass and plastic bottles, and are then sold to retailers directly or, through wholesalers or other bottlers. Outside the United States, the Company also sells concentrates for fountain beverages to its bottling partners.

The Company's finished product operations consist of Company-owned or controlled bottling, sales and distribution operations, including Coca-Cola Refreshments (CCR) bottling and associated supply chain operations in the United States and Canada, and are included in its Bottling Investments operating segment. In addition, in the United States, the Company manufactures fountain syrups and sells them to fountain retailers, such as restaurants and convenience stores using fountain syrups to produce beverages for immediate consumption, or to authorized fountain wholesalers or bottling partners reselling the fountain syrups to fountain retailers. These fountain syrup sales are included in its North America operating segment. Its finished product operations include selling of sparkling beverages and a range of still beverages, such as juices and juice drinks, energy and sports drinks, ready-to-drink teas and coffees, and certain water products, to retailers or to distributors, wholesalers and bottling partners distributing them to retailers.

The Company and certain of its bottlers distribute certain brands of Monster Beverage Corporation (Monster), primarily Monster Energy, in designated territories in the United States, Canada and other international territories. The Company produces and/or distributes certain third-party brands, including brands owned by Dr Pepper Snapple Group, Inc., which it produces and distributes in designated territories in the United States and Canada. It has a joint venture with Nestle S.A. named Beverage Partners Worldwide (BPW), which markets and distributes Nestea products in Europe and Canada. It holds interest in certain territories to brands produced and distributed by Aujan Industries Company J.S.C. (Aujan), including Rani, a juice brand, and Barbican, a flavoured malt beverage brand.

The Company competes with others mega corporations as PepsiCo. Inc., Nestle S.A., Dr Pepper Snapple Group. Inc., Groupe Danone, Mondelez International. Inc., The Kraft Heinz Company, Suntory Beverage \& Food Ltd. and Unilever. 


\section{The Coca-Cola Company. Shareowners and Stock Split Policies}

On September 5, 1919, a consortium of businessmen led by Ernest Woodruff, Robert W. Woodruff's father, purchased The Coca-Cola Company for \$25 million. The business was re-incorporated as a Delaware Corporation and its stock was put on public sale on the New York Stock Exchange, with common stock at $\$ 40$ per share, and preferred stock at $\$ 100$ per share. The initial symbol used for The CocaCola Company was CCO. By 1923, the symbol "KO" replaced "CCO".

$\square$ The Coca-Cola Company began its Christmas advertising in the 1920s in an effort to increase sales during the slower winter months. Several different images of Santa were used, but none proved to be popular with consumers until 1931. That year, Archie Lee, an advertising executive for Coca-Cola, commissioned illustrator Haddon Sundblom to paint a Santa that was both wholesome and realistic. Sundblom looked to the Clement Moore poem "A Visit From St. Nicholas" and his own Scandinavian heritage to create the big, red, jolly vision of Santa that the Company used for more than 30 years. The Company commissioned Sundblom to paint Santa for the last time in 1964, but by then, the popular image of Santa was the Coca-Cola Santa Claus.

The Coca-Cola Company is now a publicly traded company; in other words, the owners of Coca-Cola are the shareholders. Technically, thousands of people own Coca-Cola today. Most of these owners are other organizations and groups of people. This ownership is divided among 2,418 institutions.

$\square$ The majority shareholder of Coca-Cola Company is Warren Buffet through his company, Berkshire Hathaway, Inc. Buffet made it clear in 2013 that he would never sell his Coca-Cola shares. Buffet took an interest in and saw the profitability of Coca-Cola as a company when he was only seven years old.

Coca-Cola insiders own 0.77 percent of the shares. The directors and top management make up the majority of owners within the company. The total share for insiders is only 0.77 percent of all shares, but the board of directors, led by chairman and C.E.O, makes the decisions for the Coca-Cola Company. The board of directors works closely with other managers from different regions and departments.

There are a few differences between standardized options and employee stock options. Firstly, the terms of employee stock options are not fixed while exchange traded options have standardized terms. Secondly, employee stock options are not traded on exchanges whereas standardized options are traded. Finally, employee stock options generally are not transferable while standardized options are interchangeable and can be freely traded on any exchange that lists them.

Coca-Cola, through an equity compensation plan, offers managers incentives of 
stock ownership and stock split - a real stake in the business - if certain business goals are met.

As a public company with shareowners big and small, The Coca-Cola Company believes it is important to form an equity plan in simple terms.

Shareownership and stock split presume an equity plan in which a portion of the compensation for a large group of managers is provided - in the short and in the long term - in the form of stock options and 'performance units' that are linked to the company's performance.

A stock split is a decision by a company's board of directors to increase the number of shares that are outstanding by issuing more shares to current shareholders. For example, in a 2-for-1 stock split, an additional share is given for each share held by a shareholder. A stock split or stock divide increases the number of shares in a company. The price is adjusted such that the before and after market capitalization of the company remains the same and dilution does not occur. A company may split its stock, for example, when the market price per share is so high that it becomes unwieldy when traded.

Figure 1: The Coca-Cola Company. 57 Year Stock Price History (1962-2019)

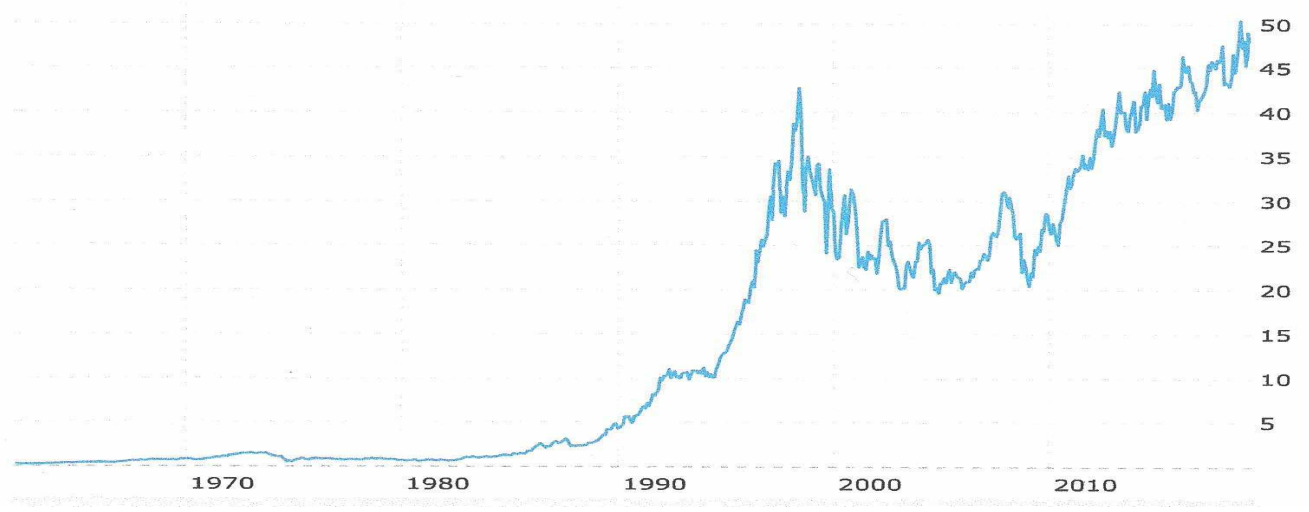

Anyway, a stock split program is strictly linked to the corporate market value (Figure 1), but first it is really focused to preserve the corporate value of keymanagers as primary shareholders.

Coca-Cola $(\mathrm{KO})$ has 9 splits in the Coca-Cola stock split history database (Table 1). The first split for KO was a 2 for 1 split, meaning for each share of KO owned pre-split, the shareholder now owned 2 shares. For example, a 1,000 share position pre-split, became a 2,000 share position following the split. When a company such as Coca-Cola splits its shares, the market capitalization before and after the split takes place remains stable, meaning the shareholder now owns more shares but each are valued at a lower price per share. Often, however, a lower priced stock on a per-share basis can attract a wider range of buyers. If that increased demand causes the share price to appreciate, then the total market capitalization rises post-split. 
Looking at the Coca-Cola stock split history from start to finish, an original position size of 1,000 shares would have turned into 768,000 today.

Table 1: KO Split History Table

$\begin{array}{ll}\text { Date } & \text { Ratio } \\ 02 / 19 / 1965 & 2 \text { for } 1 \\ 05 / 19 / 1965 & 2 \text { for } 1 \\ 06 / 03 / 1968 & 2 \text { for } 1 \\ 06 / 01 / 1977 & 2 \text { for } 1 \\ 07 / 01 / 1986 & 3 \text { for } 1 \\ 05 / 14 / 1990 & 2 \text { for } 1 \\ 05 / 12 / 1992 & 2 \text { for } 1 \\ 05 / 13 / 1996 & 2 \text { for } 1 \\ 08 / 13 / 2012 & 2 \text { for } 1\end{array}$

It is so clear that in the short term, the value of management compensation as shareowners depends on the increase in the value of the company. If the actions taken by the people running the business result in growth, then the stock price goes up and they benefit. Similarly, if the business does not perform as well, it is likely that the stock price will reflect that and those managers will receive less compensation. The Company defines this policy a 'pay for performance' and the goal is to promote the success of The Coca-Cola Company by linking the personal interests of employees to those of shareowners. If the Company does not perform, managers do not benefit.

$\square$ I believe shareowners want to put their money in companies they can count on, day in and day out... To be of unique value to our owners over the long haul, we must also be of unique value to our consumers, our customers, out bottling partners, our fellow employees and all other stakeholders - over the long haul. Accordingly, that is how the long-term interests of the stakeholders are served - as the long-term interests of the shareowners are served. Likewise, unless the long-term interests of the shareowners are served, the long-term interests of the stakeholders will not be served. The real possibility for conflict, then, is not between shareowners and stakeholders, but between the long-term and the short-term interests of both. The creation of unique value for all stakeholders, including shareowners, over the long haul, presupposes a stable, health society. The exercise of what is commonly referred to as 'corporate responsibility' is a supremely rational, logical corollary of a company's essential responsibility to the long-term interests of its shareowners... in the main, our shareowners look to us to deliver sustained, longterm value. At The Coca-Cola Company, we have built our business and grown it profitably for more than 110 years... 
Ultimately, the mission of this Atlanta soft-drink Company - and my 26,000 associates - is not simply to sell an extra case of CocaCola. Our mission is to create value over the long haul for the owners of our Company. The best way for us to serve all our stakeholders - not just our shareowners, but also our fellow employees, our business partners and our communities - is by creating value over time for those who have hired us (Gouizeta R.C., 1997).

The Coca-Cola Company believes that proposed equity plan is financially sound and encourages employees to act like owners by tying their interests to those of everyone who owns a share of The Coca-Cola Company. In brief, 'we want our employees to think and act like owners' (Bowden, 2014). In summary, the CocaCola Company accountability for sustainability creates a range of outcomes including diverse beverage products; economic benefits such as jobs, taxes paid and community investment; ecosystem impacts and initiatives; and customer and shareowner value.

The Coca-Cola Company defines high standards for the people at all level and strives to meet these standards consistently. The Company's board of directors has established a number of committees to assist in discharging its duties.

The board's Public Issues and Diversity Review Committee keeps TheCoca-Cola Company abreast of the ways broad societal and environmental trends may impact the interests of shareowners and other stakeholders. Throughout the year, the Committee receives detailed briefings and updates about progress against Coca-Cola's sustainability goals. This is critical to fulfilling its responsibility to provide oversight of the company's sustainability commitments, actions and results (Kent \& Herman, 2018).

The Public Issues and Diversity Review Committee helps the board fulfil responsibilities relating to diversity, sustainability, corporate social responsibility and public issues of significance, especially with regard to the ways in which these issues may affect the shareowners, the company, the communities in which the Company operates, and the general public. The committee reviews, at least annually, all shareowner proposals, public policy advocacy efforts, political contributions and charitable contributions to ensure alignment with company policy and overall values. The Coca-Cola Company has robust programs in place to identify issues for the business and stakeholders, and cross-functional teams working across the system. Beyond the internal Enterprise Risk Management team, this also includes the work of the Company's dedicated Stakeholder Engagement function that partners with business units, bottling partners, NGOs, governments, and people in communities all around the world. 


\section{Bibliography}

Adamson, G., \& Gordon D. (2003). Industrial Strength Design: How Brooks Stevens Shaped Your World. Cambridge: MIT Press.

Agyemang, G., \& Broadbent, J. (2015). Management Control Systems and Research Management in Universities: An Empirical and Conceptual Exploration, Accounting Auditing \& Accountability Journal, September, 28(7), 1018-1046.

http://dx.doi.org/10.1108/AAAJ-11-2013-1531

Baur, C., \& Wee, D. (2015). Manufacturing's Next Act, McKinsey \& Company, June.

Bosetti, L. (2015). Social Networks and Stakeholder Engagement. Evidence from Global Compact Lead Participants, Journal of Strategic and International Studies, 10(6), 44-56.

Bowden, G. (2014). The Coca-Cola Company Letter, March 28.

Brondoni, S. M. (2018). Competitive Business Management and Global Competition. An Introduction, in Brondoni, S. M. (ed.), Competitive Business Management. A Global Perspective, Routledge \& Giappichelli, New York \& Turin.

Brondoni, S. M. (2018). Planned Obsolescence, Total Quality, Zero Defects and Global Competition, Symphonya. Emerging Issues in Management (symphonya.unimib.it), 2, 8-20.

http://dx.doi.org/10.4468/2018.2.02brondoni

Brondoni, S. M., \& Bosetti, L. (2018). Ouverture de 'Integrated CSR Management', Symphonya. Emerging Issues in Management (symphonya.unimib.it), 1, 1-17.

http://dx.doi.org/10.4468/2018.1.01ouverture

Brondoni, S. M, \& Zaninotto, E. (2018). Ouverture de 'The 4th Industrial Revolution. Business Model Innovation \& Global Competition', Symphonya. Emerging Issues in Management (symphonya.unimib.it), 2, 1-7.

http://dx.doi.org/10.4468/2018.2.01ouverture

Brondoni, S. M. (2015). Global Networks, Outside-In Capabilities and Smart Innovation, Symphonya, Emerging Issues in Management (symphonya.unimib.it), (1), 6-21.

http://dx.doi.org/10.4468/2015.1.02brondoni

Brondoni, S. M. (2014). Global Capitalism and Sustainable Growth. From Global Products to Network Globalisation, Symphonya. Emerging Issues in Management (symphonya.unimib.it), 1, 10-31.

http://dx.doi.org/10.4468/2014.1.02brondoni

Brondoni, S. M. (2013). Innovation and Imitation for Global Competitive Strategies. The Corporation Development Models of US, Japan, Korea, and Taiwan, Symphonya. Emerging Issues in Management (symphonya.unimib.it), (1), 12-27.

http://dx.doi.org/10.4468/2013.1.02brondoni

Brondoni, S. M. (2012). Innovation and Imitation: Corporate Strategies for Global Competition, Symphonya. Emerging Issues in Management (symphonya.unimib.it), (1), 10-24.

http://dx.doi.org/10.4468/2012.1.02brondoni

Brondoni, S. M. (2011). Global Networks, Knowledge Management and World Cities, Symphonya. Emerging Issues in Management (symphonya.unimib.it), (1), 7-18.

http://dx.doi.org/10.4468/2011.1.02brondoni

Brondoni, S. M. (2003). Network Culture, Performance \& Corporate Responsibility, Symphonya. Emerging Issues in Management (symphonya.unimib.it), 1, 8-24.

http://dx.doi.org/10.4468/2003.1.02brondoni

Cantino, V., \& Cortese, D. (2017). Integrated Report System: Purposes and Benefits of the Italian Law, Symphonya. Emerging Issues in Management (symphonya.unimib.it), 1, 83-94.

http://dx.doi.org/10.4468/2017.1.07cantino.cortese 
Clarke, J. (1997). Shareholders and Corporate Community Involvement in Britain. Business Ethics, 6(4), 201-207.

http://dx.doi.org/10.1111/1467-8608.00070

Clarkson, M. B. E. (1995). A Stakeholder Framework for Analysing and Evaluating Corporate Social Performance, The Academy of Management Review, 20(1), 92-117.

http://dx.doi.org/10.3138/9781442673496-013

Donaldson, T., \& Preston, L. (1995). The Stakeholder Theory of the Corporation: Concepts, Evidence and Implications, The Academy of Management Review, 20(1), 65-91.

http://dx.doi.org/10.2307/258887

Eccles, R. G., \& Krzus, M.P. (2010). One Report. Integrated Reporting for a Sustainable Strategy, Hoboken, New Jersey: John Wiley \& Sons.

Freeman, R. E., \& Dmytriyev, S. (2017). Corporate Social Responsibility and Stakeholder Theory: Learning From Each Other, Symphonya. Emerging Issues in Management (symphonya.unimib.it), 2, 7-15.

http://dx.doi.org/10.4468/2017.1.02freeman.dmytriyev

Freeman, R. E. (1984). Strategic Management: a Stakeholder Approach. Boston: Pitman.

Friedman, M. (1970), The Social Responsibility of Firms is to Increase its Profits, New York Times Magazine.

Goizueta, R. C. (1997). The Coca-Cola Company's 1997 Annual Report.

Haider, M. B., \& Kokubu, K. (2015). Assurance and Third-Party Comment in Sustainability Reporting in Japan: A Descriptive Study, International Journal of Environment and Sustainable Development, 14(3), 207-230.

http://dx.doi.org/10.1504/IJESD.2015.070133

Hewitt-Dundas, N., \& Roper, S. (2017). Exploring Market Failures in Open Innovation, 36, International Small business Journal, 1, 23-40.

http://doi.org/10.1177/0266242617696347

Kent, M., \& Herman, A. (2018). The Coca-Cola Company. Business \& Sustainability Report.

Klettner, A., Clarke, T., \& Boersma, M. (2014). The Governance of Corporate Sustainability: Empirical Insights into the Development, Leadership and Implementation of Responsible Business Strategy, Journal of Business Ethics, 122(1), 145-165.

http://dx.doi.org/10.1007/s10551-013-1750-y

Lambin, J. J. (2018). The Sharing Economy. A New Strategy to Compete in the Global Market, in Brondoni, S. M. (ed.), Competitive Business Management. A Global Perspective, Routledge \& Giappichelli, New York \& Turin.

Lambin, J. J. (2014). Rethinking the Market Economy. Symphonya. Emerging Issues in Management (symphonya.unimib.it), 2, 4-15.

http://dx.doi.org/10.4468/2014.2.02lambin

Marston, C. L., \& Polei, A. (2004). Corporate Reporting on the Internet by German Companies, International Journal of Accounting Information System, 5(3), 285-311.

http://dx.doi.org/10.1016/j.accinf.2004.02.009

Mosca, F., \& Civera, C. (2017). The Evolution of CSR: An Integrated Approach. Symphonya. Emerging Issues in Management (symphonya.unimib.it), 1, 16-35.

http://dx.doi.org/10.4468/2017.1.03mosca.civera

Mosca, F., Tamborrini, P., \& Casalegno, C. (2015). Systemic Design: How to Compete by Leveraging the Value System, Symphonya. Emerging Issues in Management (symphonya.unimib.it), 2, 42-56.

http://dx.doi.org/10.4468/2015.2.04mosca.tamborrini.casalegno

Porter, M. E., \& Kramer, M. R. (2011). Creating Shared Value. Harvard Business Review, 89 (1/2), 62-77. 
Rogate, C. (2017). Sharing Responsibilities for Sustainable Development, Symphonya. Emerging Issues in Management (symphonya.unimib.it), 1, 66-82.

http://dx.doi.org/10.4468/2017.1.06rogate

Sabet E., Adams E., \& Yazdani, B. (2016) Quality management in heavy duty manufacturing industry: TQM vs. Six Sigma, Total Quality Management \& Business Excellence, 27(1-2), 215225.

http://dx.doi.org/10.1080/14783363.2014.972626

Salvioni D. M. (2018). Corporate Governance, Ownership and Global Markets, in Brondoni, S. M. (ed.), Competitive Business Management. A Global Perspective, Routledge \& Giappichelli, New York \& Turin.

Salvioni, D. M. (2016). Hotel Chains and the Sharing Economy in Global Tourism, Symphonya. Emerging Issues in Management (symphonya.unimib.it), (1), 31-44.

http://dx.doi.org/10.4468/2016.1.04salvioni

Salvioni, D. M., Gennari, F., \& Bosetti, L. (2016). Sustainability and Convergence: The Future of Corporate Governance Systems? Sustainability, 8(11): 1203.

http://dx.doi.org/10.3390/su8111203

Salvioni, D. M., \& Bosetti, L. (2014). Stakeholder Engagement and Integrated Reporting: Evidence From the Adoption of the IIRC Framework, Journal of Strategic and International Studies, 9(3), 78-89.

Salvioni, D. M., \& Bosetti, L. (2014). Sustainable Development and Corporate Communication in Global Markets, Symphonya. Emerging Issues in Management (symphonya.unimib.it), 1, 32-51.

http://dx.doi.org/10.4468/2014.1.03salvioni.bosetti

Salvioni, D. M., \& Astori, R. (2013). Sustainable Development and Global Responsibility in Corporate Governance, Symphonya. Emerging Issues in Management (symphonya.unimib.it), 1, 28-52.

http://dx.doi.org/10.4468/2013.1.03salvioni.astori

Salvioni, D. M. (2003). Corporate Governance and Global Responsibility. Symphonya. Emerging Issues in Management (symphonya.unimib.it), 1, 2003, 44-54.

http://dx.doi.org/10.4468/2003.1.05salvioni

Salvioni, D. M. (2002). Transparency Culture and Financial Communication, Symphonya. Emerging Issues in Management (symphonya.unimib.it), 2, 22-33.

http://dx.doi.org/10.4468/2002.2.04salvioni

Severo, E. A., de Guimarães, J. C. F., \& Henri Dorion, E. C. (2018). Cleaner Production, Social Responsibility and Eco-Innovation: Generations' Perception for a Sustainable Future, Journal of Cleaner Production, 186, 91-103.

http://dx.doi.org/10.1016/j.jclepro.2018.03.129

Suchman, M. C. (1995). Managing Legitimacy: Strategic and Institutional Approaches, The Academy of Management Journal, 20(3), 571-610. http://dx.doi.org/10.5465/AMR.1995.9508080331

Sushila, S., \& Amol, D. (2016). A Study of Corporate Web-Based Reporting in Hotel Industry, Asian Economic and Financial Review, 6(11), 661-680.

http://dx.doi.org/10.18488/journal.aefr/2016.6.11/102.11.661.680

Unerman, J., \& Bennett, M. (2004). Increased Stakeholder Dialogue and the Internet: Towards Greater Corporate Accountability or Reinforcing Capitalist Hegemony? Accounting, Organizations and Society, 29(7), 685-707.

http://dx.doi.org/10.1016/j.aos.2003.10.009 